九州大学学術情報リポジトリ

Kyushu University Institutional Repository

\title{
Identification of Agents Causing Brown Rot of Cymbidium iridioides in Sa Pa, Lao Cai Province, Vietnam
}

Nguyen, $\mathrm{Ha} \mathrm{T}$.

Department of Molecular Plant Pathology, Agricultural Genetics Institute

Nguyen, Ha T. T.

Department of Molecular Plant Pathology, Agricultural Genetics Institute

Pham, Ho i X.

Department of Molecular Plant Pathology, Agricultural Genetics Institute

Le, Ham $H$.

Department of Molecular Plant Pathology, Agricultural Genetics Institute

他

https://doi.org/10.5109/1526289

出版情報: 九州大学大学院農学研究院紀要. 60 (1)，pp. 1-6，2015-02-27. Faculty of Agriculture， Kyushu University

バージョン :

権利関係 : 


\title{
Identification of Agents Causing Brown Rot of Cymbidium iridioides in Sa Pa, Lao Cai Province, Vietnam
}

\section{Ha T. NGUYEN ${ }^{1}$, Ha T.T. NGUYEN ${ }^{1}$, Hoi X. PHAM ${ }^{1}$, Ham H. LE ${ }^{1}$, Naruto FURUYA ${ }^{2}$, Kenichi TSUCHIYA ${ }^{2}$ and Long H. HOANG ${ }^{1 *}$}

\author{
Laboratory of Plant Pathology, Division of Agricultural Biological Science, \\ Department of Bioresource Science, Faculty of Agriculture, \\ Kyushu University, Fukuoka 812-8581, Japan \\ (Received October 2, 2014 and accepted November 14, 2014)
}

\begin{abstract}
Cymbidium orchid (Cymbidium iridioides) is widely cultivated in Northern mountainous provinces of Vietnam, especially in $\mathrm{Sa} \mathrm{Pa}$, Lao Cai province. However, severe outbreaks of brown rot disease in $C$. iridioides occurred in July, 2013 due to abnormal weather conditions that resulted in significant loss for growers. In order to identify exactly the causal agent of the disease, the infested samples were collected. Twentyfive bacterial isolates were selected and no fungus was present in the samples. Pectolytic activity of those bacterial isolates was determined on potato tuber slices and the virulence was assessed on cymbidium cut leaves in vitro. As results, three bacterial isolates [M3(1), M3(2) and M4(3)] induced different rot symptoms on potato tuber slices and cymbidium cut leaves. Based on their bacteriological characteristics and 16S rRNA gene sequence analysis, these bacterial isolates M3(1), M4(3) and M3(2) were identified as Pectobacterium carotovorum subsp. carotovorum, P. carotovorum and Pseudomonas sp., respectively. The results suggested that bacterial brown rot disease of $C$. iridioides in $\mathrm{Sa} \mathrm{Pa}$, Lao Cai province, might involve three causal bacterial species.
\end{abstract}

Key words: Pectobacterium carotovorum subsp. carotovorum, Pectobacterium carotovorum, Pseudomonas sp., brown rot, Cymbidium iridioides

\section{INTRODUCTION}

Cymbidium iridioides is one of the most beautiful cymbidium orchids used in the cut-flower trade and for potted plants because of its natural characteristics such as leaf shape, colors, large sized and long-lasting blooms, the texture of the flowers as well as the number of flowers per plant (Kaenratana, 2009). Vietnam is a tropical country with large cover of forests that are favorable for growing wild orchids. In addition, there have been a large number of precious orchid species and high potentials of wild plant species as well as diversified germplasm in Vietnam. High land plateau regions such as $\mathrm{Sa} \mathrm{Pa,} \mathrm{Moc}$ Chau, Ba Vi and Da Lat are suitable for growing different orchid species. However, abnormal weather conditions, uncontrolled deforestation and disease outbreaks are leading to extinct risks of many precious orchid species.

Orchids have been known to be infected by bacteria of the genus Pectobacterium (syn. Erwinia) (Hauben et al., 1998; Cating and Palmateer 2011). Strider (1985) described soft rot caused by Erwinia carotovora (Jones) Holland, which affected a wide range of vegetable and ornamental plants. Though it is not common on orchids, the disease can be the most destructive one. Since early 1989, rotting diseases of Dendrobium sp. and Phalaenopsis sp. were commonly observed in the campus of University of Pertanian Malaysia on all stages of

\footnotetext{
Department of Molecular Plant Pathology, Agricultural Genetics Institute, Pham Van Dong, Hanoi, Vietnam

${ }^{2}$ Laboratory of Plant Pathology, Department of Agricultural Bioresource Science, Faculty of Agriculture, Kyushu University, Fukuoka 812-8581, Japan

* Corresponding author (E-mail: longhh.agi@mard.gov.vn)
}

plant growth. The disease was observed to become severer during the wet periods and on Phalaenopsis hybrids (Abdullah and Kadzimin, 1993). Root decay in orchids obstructs uptake of water and nutrients, causing yellowing and shriveling of the leaves. A brown-black rot can extend into the pseudobulbs and leaves from the root system, depending on the host response to infection and environmental conditions. The disease symptoms commonly result in the death of the plant. Several organisms have been implicated in this disease, in particular, Pythium ultimum Trow., Phytophthora cactorum (Leb. \& Cohn.) Schroet, Rhizoctonia spp. and Fusarium spp. (Burnett, 1986). Preliminary investigations had shown that Fusarium spp. were the most frequently isolated fungi associated with diseased orchids grown in glasshouses in the Sydney region (Benyon et al., 1996). Sclerotium rot caused by Sclerotium rolfsii has been found to occur on cymbidium orchids (Cymbidium spp.), which are economically important cultivated potted flower plants, in Korea. In July 2010, symptoms of basal rot of the pseudobulbs were observed on cymbidium orchids in a commercial field in Seosan-si, Chungcheongnam-do, Korea (Han et al., 2012).

In a disease survey of Cymbidium spp. in $\mathrm{Sa} \mathrm{Pa}$, Lao Cai province, Vietnam, it was reported that in 2011 there were eight diseases including bacterial soft rot, anthracnose, leaf spot, gray mold, leaf blight, Fusarium wilt, Sclerotium rot and black spot in three major Cymbidium species. Bacterial soft rot and anthracnose caused by $P$. carotovorum and Colletotrichum crassipes, respectively, were the most prevalent diseases. The disease incidence reached up 40\% in open fields under warm and high humidity climate conditions (Duyen and Tuat, 2012). 
Consistently, in 2012, severe outbreaks of soft rot disease in C. iridioides occurred in $\mathrm{Sa} \mathrm{Pa}$, Lao Cai province. The causal agent was firstly identified as $P$. carotovorum (Ha et al., 2013). The current study was conducted to determine causal agents of bacterial brown rot of $C$. iridioides in this province in 2013.

\section{MATERIALS AND METHODS}

\section{Isolation of bacterial isolates from infected sam- ples}

Isolation of causal agents from infected leaves was carried out as described by Furuya et al. (2012) with some modifications. Briefly, the infected leaves were washed under running tap water and cut into small pieces $2 \times 2 \mathrm{~cm}$. The diseased leaf samples were dipped in $70 \%$ ethanol for few seconds, subsequently in 3\% sodium hypochlorite solution (Sigma, Steinheim, Germany) for $2 \mathrm{~min}$, and rinsed three times in sterilized distilled water (SDW). After surface disinfection, leaf tissues were titrated in SDW; appropriate dilutions of bacterial suspension were plated onto YPDA (yeast peptone dextrose agar medium: yeast extract $3 \mathrm{~g}$, peptone $0.6 \mathrm{~g}$, dextrose $3 \mathrm{~g}$, agar $20 \mathrm{~g}$, distilled water 1 liter, $\mathrm{pH} 7$ ) and incubated at $30^{\circ} \mathrm{C}$ for $2-10$ days. After incubation, distinct colonies were picked from the plates. Purified cultures were suspended in $10 \%$ skimmed milk and stored at $-30^{\circ} \mathrm{C}$ for preservation.

In order to check the presence of fungi in the infected leaves, the disinfected ones were stained with $0.01 \%(\mathrm{w} / \mathrm{v})$ acid fuchsin in lactoglycerol (lactic acid-glycerol-water, 1:1:1 and observed under light microscope (Vierheilig et al., 2005). At the same time, small pieces of the infected leaves were plated on PDA medium (potato dextrose agar medium: potato $200 \mathrm{~g}$, dextrose $20 \mathrm{~g}$, agar $20 \mathrm{~g}$ and distilled water 1 liter) and incubated at $28^{\circ} \mathrm{C}$ for 7 days.

\section{Characterization of pectolytic activity of bacterial isolates}

The ability of bacterial isolates to macerate plant tissues confirms its pectolytic nature and it provides an indication of pathogenicity. Potato tubers were used to test maceration ability of bacterial isolates as described by De Boer and Kelman (2001) with some modifications. Disinfection of potato tuber surface was done by immersing in $70 \%$ ethanol for $5 \mathrm{~min}$ and air-dry. The disinfected tubers were cut into small pieces with thickness of about $1 \mathrm{~cm}$, placed them in a Petri dish on moist sterile filer paper and inoculated with bacterial culture from a 24-h-old-culture using sterile toothpick. P. carotovorum subsp. carotovorum (PCc) ATCC15713 ${ }^{\mathrm{T}}$ was used as a positive control. Negative control was toothpick with SDW. The dishes were incubated at $28^{\circ} \mathrm{C}$ for $48 \mathrm{~h}$ and the tissues were checked with a spatula or toothpick to determine whether decay and tissue maceration has occurred.

\section{Pathogenicity test of bacterial isolates on cymbid- ium leaves}

Healthy cymbidium leaves were used for pathogenicity test of bacterial isolates. The inoculation procedure was conducted as pectolytic activity assay mentioned above except the inoculated leaves were recorded $24 \mathrm{~h}$, $48 \mathrm{~h}$ and $96 \mathrm{~h}$ after inoculation.

\section{Bacteriological characterization of bacterial iso- lates}

The pathogenic isolates were selected to characterize their bacteriological properties. The procedures were carried out as described by Schaad (2001).

\section{Identification of bacterial isolates using $16 \mathrm{~S}$ rRNA sequencing}

Immediately after the establishment of pure bacterial cultures, genomic DNA was isolated from one-day-old cultures grown on YPDA plates. Single colonies were suspended in SDW to obtain concentration at approximately $10^{5} \mathrm{cfu} \mathrm{m}^{-1}$ and $0.5 \mu \mathrm{l}$ were mixed with $4.5 \mu \mathrm{l}$ extraction buffer (10 mM Tris-HCl pH 7.6; $50 \mathrm{mM} \mathrm{KCl;} \mathrm{0.1 \%} \mathrm{Tween}$ 20). Then the mixture was heated at $100^{\circ} \mathrm{C}$ for $10 \mathrm{~min}$ and immediately placed on ice bath. After centrifugation at $6,000 \times g$ for $5 \mathrm{~min}$, the supernatant was used for PCR. Amplification of $16 \mathrm{~S}$ rDNA was performed in a $10 \mu \mathrm{l}$ final volume containing $1 \mu \mathrm{l}$ of genomic DNA, $10 \mu \mathrm{M}$ of primer F27 (5'-AGAGTTTATCMTGGCTCAG-3') (Edwards et al., 1989) and R1492 (5'-GRTACCTTGTTACGACTT-3') (Lane, 1991), $10 \mathrm{mM}$ of each dNTP, $5 \mathrm{mM} \mathrm{MgCl}_{2}$ and 0.05 U of Taq DNA polymerase (Eppendorf, Hamburg, Germany). A negative control (PCR mixture without DNA template) was included in all PCR experiments. The reaction conditions were as follows: $95^{\circ} \mathrm{C}$ for $2 \mathrm{~min}$ followed by 30 cycles of denaturation at $95^{\circ} \mathrm{C}$ for $15 \mathrm{~s}$, annealing at $55^{\circ} \mathrm{C}$ for $20 \mathrm{~s}$ and primer extension at $72^{\circ} \mathrm{C}$ for $1 \mathrm{~min}$, followed by a final extension at $72^{\circ} \mathrm{C}$ for $5 \mathrm{~min}$. The quality of the PCR reaction was examined by running an aliquot of the PCR mixture in $1.2 \%(\mathrm{w} / \mathrm{v})$ agarose containing ethidium bromide.

Direct sequencing using the primer F27/R1492 with expected size approximately $900 \mathrm{bp}$ was conducted in Big Dye Mix (Applied Biosystems, Foster City, CA, USA) and purification of sequencing reactions was performed using NucleoSEQ Kit (Macherey-Nagel, Duren, Germany) and sequenced on a ABI310 sequencer (Applied Biosystems; http://www.appliedbiosystems.com). The editing of sequences was performed with MEGA 5 (Tamura et al., 2011). Analysis of sequences was carried out with basic sequence alignment BLAST program (Altschul et al., 1997) run against the database from National Center for Biotechnology Information (http:// www.ncbi.nlm.nih.gov/BLAST). The sequences were deposited in GenBank (http://www.ncbi.nlm.nih.gov/ Genbank/) with the accession numbers KF971360-KF971362. Alignment with related sequences from type strains in GenBank, bootstrap calculations and phylogenetic tree construction were analyzed by the Maximum Likelihood (ML) method using MEGA 5 (Tamura et al., 2011). Distances, including pair-wise deletions and insertions, were calculated according to Jukes-Cantor model (Jukes \& Cantor, 1969), whereupon the Maximum Likelihood phylogenetic dendrogram was inferred, rooted and bootstrapped 1000 times 
(Felsenstein, 1985). Providencia sp. L16 was designated as the outgroup in the phylogenetic tree.

\section{RESULTS}

Isolation of bacterial isolates from infected leaves

The leaves of $C$. iridioides showing symptoms on the basal parts appeared as brown to dark-brown lesion (Fig. 1) were selected for isolation of bacterial pathogens. No fungal mycelia or spores were found when they were observed under microscope and on PDA medium after 7 days. A total of 25 bacterial isolates were obtained from 10 infected leaves. Most of bacterial isolates have
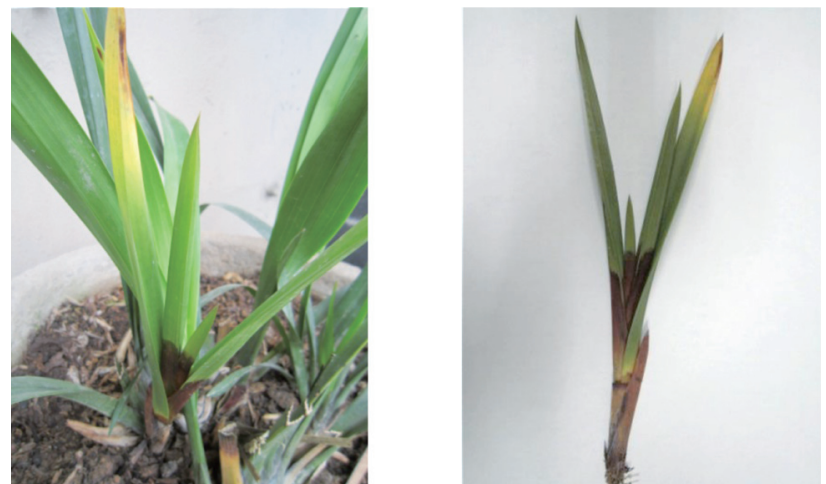

Fig. 1. Disease symptom on Cymbidium iridioides.

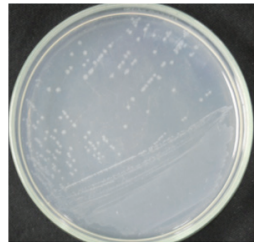

M3(1)

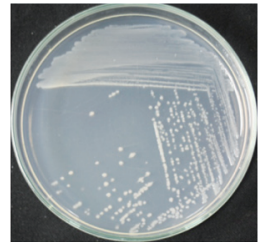

M3(2)

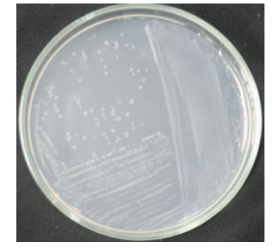

M4(3)
Fig. 2. Colonies on YPDA medium of present isolates causing brown rot in Cymbidium iridioides.

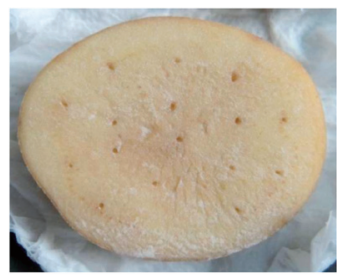

Control colony morphology of small, smooth surface and uniform on YPDA medium when incubated at $28^{\circ} \mathrm{C}$ after $48 \mathrm{~h}$ (Fig. 2).

Table 1. Pathogenicity of bacterial isolates

\begin{tabular}{|c|c|c|}
\hline $\begin{array}{l}\text { Bacterial } \\
\text { isolates }\end{array}$ & $\begin{array}{l}\text { Pectolytic activity on } \\
\text { potato tuber slices }\end{array}$ & $\begin{array}{c}\text { Pathogenicity on cymbidium } \\
\text { leaf cuttings }\end{array}$ \\
\hline M1(1) & - & - \\
\hline M1(2) & - & - \\
\hline M1(3) & \pm & - \\
\hline M1(4) & - & - \\
\hline M1(5) & - & \pm \\
\hline M2(1) & - & - \\
\hline M2(2) & - & - \\
\hline M2(3) & \pm & - \\
\hline M3(1) & + & + \\
\hline M3(2) & + & + \\
\hline M3(3) & - & \pm \\
\hline M3(4) & - & - \\
\hline M4(1) & \pm & - \\
\hline $\mathrm{M} 4(2)$ & - & - \\
\hline M4(3) & + & + \\
\hline M4(4) & \pm & - \\
\hline M4(5) & - & - \\
\hline M5(1) & - & - \\
\hline M5(2) & - & - \\
\hline M5(3) & - & - \\
\hline M5(4) & \pm & - \\
\hline M5(5) & - & - \\
\hline M6(1) & - & \pm \\
\hline M6(2) & - & - \\
\hline M6(3) & - & - \\
\hline
\end{tabular}

Note: -, negative; \pm , unclear + , positive;

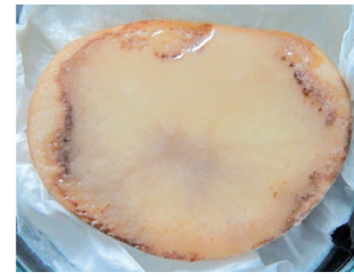

Pectobacterium subsp. carotovorum ATCC 15713

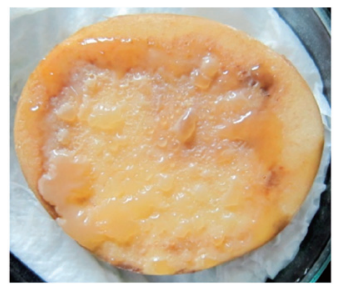

M3(1)

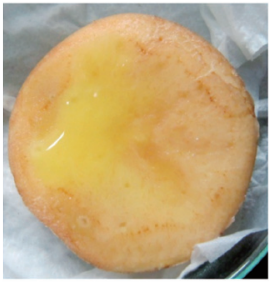

M3(2)

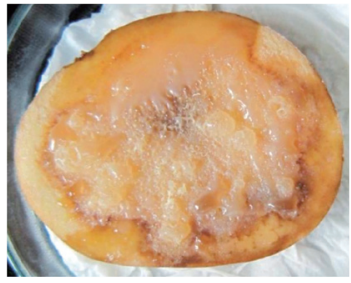

M4(3)

Fig. 3. Maceration activity on potato tuber slices. (24h after inoculation) 


\section{Pectolytic activity of bacterial isolates}

Pectolytic ability of 25 bacterial isolates was determined by showing rotting of potato tuber slices by the artificial inoculation method with toothpick. Among these isolates, three [M3(1), M3(2) and M4(3)] produced different symptoms when inoculated into potato tuber slices $24 \mathrm{~h}$ after inoculation at $28^{\circ} \mathrm{C}$ (Table 1 ). The isolate M3(1) caused the symptoms with yellowing rotted tissues in the center surrounded by dark brown edge, while M3(2) produced less severe symptoms than that of M3(1). The isolate M4(3) produced a similar symptom to that of the positive control type strain, Pcc ATCC $15713^{\mathrm{T}}$. These symptoms on potato tubers appeared as tan, water-soaked areas with watery ooze and the rot- ted tissues were white-to-cream colored (Fig. 3).

\section{Pathogenicity of bacterial isolates on cymbidium leaves}

All 25 isolates were tested for pathogenicity to their host by artificial inoculation with toothpick. Of these, three isolates M3(1), M3(2) and M4(3) were weakly to strongly pathogenic to C. iridioides (Table 1; Fig. 4). The isolate M3(2) produced no symptom on cymbidium leaves $24 \mathrm{~h}$ after inoculation, while M3(1) and M4(3) induced water-soaked areas. The symptoms on cymbidium leaves caused by M3(2) were clearly observed 96h after inoculation. The highly virulent isolates, M3(1) and M4(3), induced severe brown rot to cymbidium leaves.
$24 h$
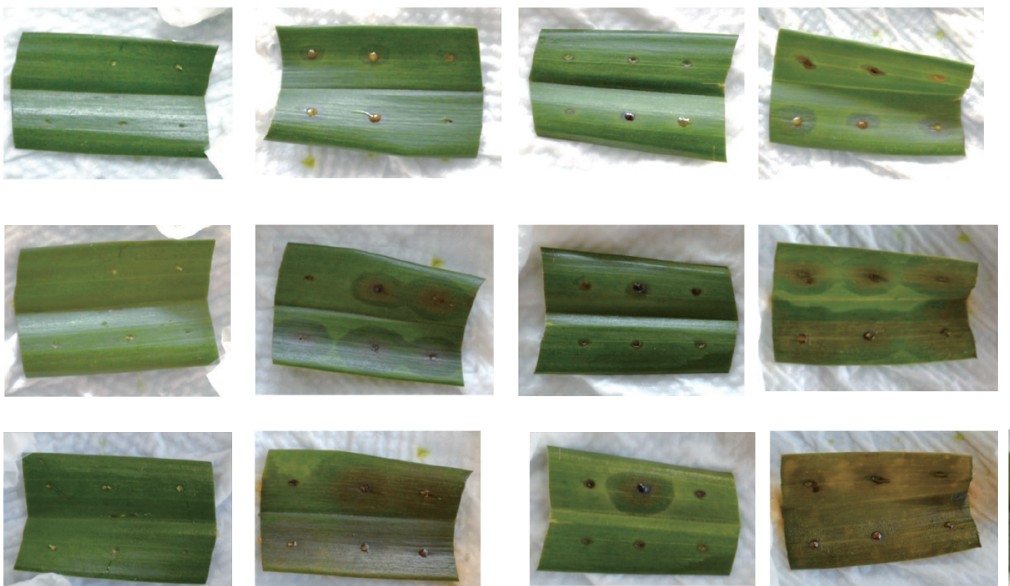

M3(1)

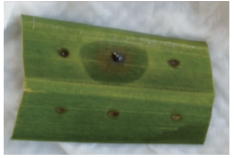

$M 3(2)$

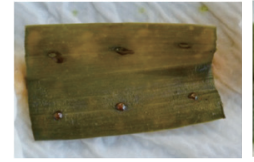

M4(3)
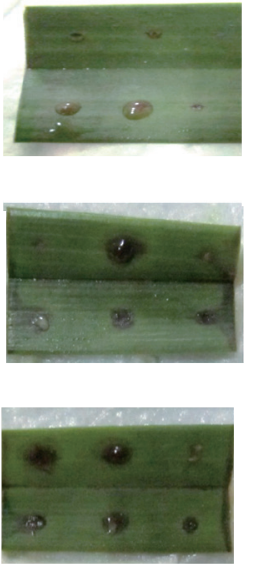

Pectobacterium subsp. carotovorum
ATCC $15713^{\mathrm{T}}$

Fig. 4. Pathogenicity of the present isolates on cymbidium leaf cuttings.

Table 2. Bacteriological characteristics of the selected bacterial isolates

\begin{tabular}{|c|c|c|c|c|}
\hline Characteristics & M3(1) & M3(2) & M4(3) & $\mathrm{Pcc}$ \\
\hline Gram reaction & - & - & - & - \\
\hline Anaerobic growth & + & - & + & + \\
\hline Aerobic growth & + & + & + & + \\
\hline Yellow colonies on YDC & - & - & - & - \\
\hline Mucoid colonies on YDC & - & - & - & - \\
\hline Fluorescent pigment on KBA & - & + & - & - \\
\hline Urease & - & - & - & - \\
\hline Oxidase & - & - & - & - \\
\hline Growth at $40^{\circ} \mathrm{C}$ & - & - & - & - \\
\hline Spores formed & - & - & - & - \\
\hline Reducing substances from sucrose & - & - & + & - \\
\hline Sensitivity to erythromycin & - & - & - & - \\
\hline \multicolumn{5}{|l|}{ Acid production from: } \\
\hline Sorbitol & + & + & + & + \\
\hline Citrate & + & - & + & + \\
\hline Arabitol & - & - & - & - \\
\hline Lactose & + & - & + & + \\
\hline
\end{tabular}

Note: -, negative; +, positive, Pcc: $P$. carotovorum subsp. carotovorum ATCC15713 


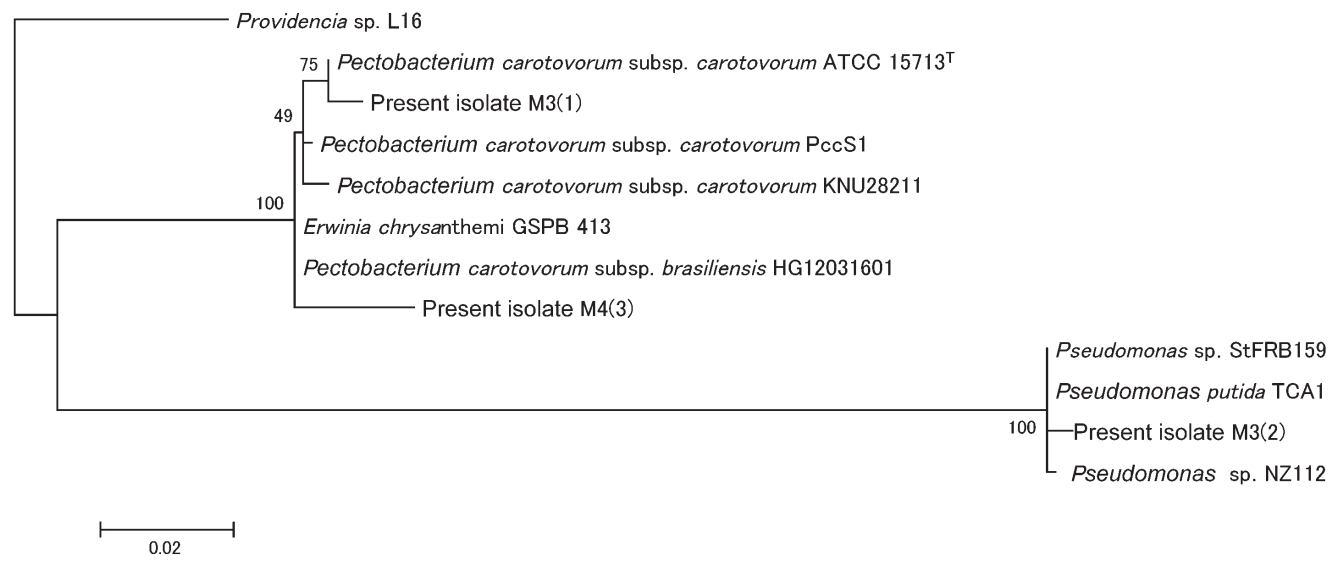

Fig. 5. Maximum Likelihood tree based on $6 \mathrm{~S}$ rDNA sequence of present isolates causing brown rot on Cymbidium iridioides.

Those symptoms progressed quickly to the whole leaf cuttings $48 \mathrm{~h}$ and $96 \mathrm{~h}$ after inoculation. The dark brownish and yellowish leaf tissues were similar to those observed in the field plants. The isolates that induced symptoms on the host plants were reisolated from the lesions. Pcc ATCC15713 ${ }^{\mathrm{T}}$ induced weak symptoms on cymbidium leaves $96 \mathrm{~h}$ after inoculation (Fig. 4).

\section{Bacteriological characteristics of bacterial brown rot agents}

Bacteriological characters of three pathogenic bacterial isolates and the type strain of PCC ATCC $15713^{\mathrm{T}}$ were described in Table 2. The isolates M3(1), M4(3) and PCC ATCC15713 ${ }^{\mathrm{T}}$ shared most of the selected characteristics, except for the positive reaction of reducing sucrose by M4(3). Characters of the isolate M3(2) were mostly different from the other isolates, particularly for the productivity of fluorescent pigment on King's B Agar medium (KBA).

\section{Identification of bacterial brown rot agents by $16 \mathrm{~S}$ rDNA gene sequencing}

Three pathogenic isolates M3(1), M3(2) and M4(3) were identified by $16 \mathrm{~S}$ rDNA gene sequencing. The partial sequences of M3(1), M3(2) and M4(3) showed 99\% identity with Pcc, Pseudomonas sp. and P. carotovorum subsp. brasiliensis (Pcb), respectively. The phylogenetic tree constructed using partial 16S rDNA sequences placed these isolates in the respective cluster (Fig. 5). Their sequence data were deposited in the GenBank under accession numbers KF971360, KF971361 and KF971362. The isolate M4(3) is closely related to $P c b$ based on the 16S rDNA sequence analysis, but further study is needed for its subspecies identification.

\section{DISCUSSION}

As expected, $P c c$ and $P$. carotovorum were isolated from cymbidium leaves with symptoms of brown rot. $P$. carotovorum is considered as a broad host range pathogen and this species has been isolated from a wide range of plant species. It has been further divided into subspe- cies of $P c c$ and $P c b$, which were most commonly found on potato. $P C c$ is typically associated with stem and tuber soft rot, although a subtype also causes blackleg. $P c b$, on the other hand, causes stem rot, tuber soft rot, and blackleg (Marquez-Villavicencio et al., 2011).

In addition to Pectobacterium species, Pseudomonas sp. M3(2) was also isolated from the infected cymbidium leaves. Krejzar et al. (2008) reported that for the first time in the Czech Republic, Pseudomonas marginalis, Pcc and P. putida were isolated from tubers of Zantedeschia spp. with symptoms of tuber soft rot. When inoculation was made into potato tuber slices, strains of P. marginalis and PCc produced brown rot. In another report, Kim et al. (2002) identified soft rot agent of onion bulbs caused by $P$. marginalis under low temperature storage.

There were different levels of aggressiveness among three pathogenic bacterial isolates in the inoculated cymbidium leaves. All three isolates caused maceration in potato tubers. However, the isolates M3(1) and M4(3) which were tentatively identified as Pcc and P. carotovorum, respectively, were the most aggressive in cymbidium leaves, whereas the type strain Pcc ATCC15713 was the least aggressive one. This finding was consistent with a previous report that a strain of Pcc obtained from calla lily was in the most aggressive group, whereas the type strain of Pcc isolated from carrot was typical of strains in the least aggressive group (Smith and Bartz, 1990). Strains isolated from a particular host were not always more aggressive than those recovered from other plants when they were inoculated to the relevant host. Thus, certain strains of Pcc might exhibit a host specificity that was not related to their original host or to their relative aggressiveness in common hosts (such as potato tuber or tomato fruit) (Smith and Bartz, 1990).

In this study, no fungus had been found in the diseased leaves of $C$. iridioides, suggesting that the disease was caused by bacterial pathogens, although some studies reported that the agents causing rot symptoms on cymbidium were fungi (Benyon et al., 1996; Han et al., 2012). In Korea, F. oxysporum was consistently isolated from dry rot lesions of six species of cymbidium plants, 
while isolation frequency of $F$. solani and $F$. proliferatum from the plants was very low. The results suggested that $F$. oxysporum was the main pathogen of the disease (Lee et al., 2002). Another study reported that Sclerotium rolfsii caused rot symptoms of the pseudobulbs on cymbidium orchids in Korea (Han et al., 2012).

Temperature and humidity might be the main factors affecting the outbreak of brown rot in cymbidium in $\mathrm{Sa} \mathrm{Pa}$, Lao Cai province, Vietnam. Our survey results showed that occurrence and development of cymbidium brown rot had important relationship with planting and climatic conditions. It was reported that the highest disease incidence was up to $40-50 \%$, both in the greenhouse as well as in open fields during the period of June and July, whereas lower incidence in August when it was cooler and less rain (Ha et al., 2013; Duyen and Tuat, 2012). Low temperature and high humidity were favorable conditions for the disease occurrence and development (Sen et al., 2009).

Our results confirm that bacterial brown rot of $C$. iridioides could be polyaetiological in nature. A number of species could cause the same symptoms and might be present in diseased tissues at the same time. A similar disease survey on $C$. iridioides in $\mathrm{Sa} \mathrm{Pa}$, Lao Cai province, Vietnam reported that soft rot diseases on leaves and stems of $C$. irridioides was caused by E. carotovora Hold (Duyen and Tuat, 2012). Sen et al. (2006) reported that three pathogens were consistently isolated from the diseased samples: namely Pcc, F. oxysporum and Mucor hiemalis f. sp. hiemalis in the early, middle and later phases of disease progression, respectively. The apparent synergistic activity of the three pathogens seems to be the cause of the uncontrolled epidemics. Therefore, our finding of co-existence of $P$. carotovorum in brown rot cymbidium leave tissues with Pseudonomas sp. is totally unexpected.

\section{ACKNOWLEDGEMENTS}

This work was conducted at Agricultural Genetics Institute and funded by Vietnam National Foundation for Science and Technology (NAFOSTED), under grant number 106.03-2012.61.

\section{REFERENCES}

Abdullah, H. and S. Kadzimin 1993 Etiology of bacterial soft rot of orchids. Pertanika J. Trop. Agric. Sci., 16(1): 1-4

Altschul, S. F., T. L. Madden, A. A. Schaffer, J. H. Zhang, Z. Zhang, W. Miller, D. J. Lipman 1997 Gapped BLAST and PSI-BLAST: a new generation of protein database search programs. Nucleic Acids Res., 25: 3389-3402

Benyon F., B. A. Summerell and L. W. Burgess 1996 Association of Fusarium species with root rot of Cymbidium orchids. Australian Plant Pathol., 2(5): 226-228

Burnett, H. C. 1986 Diseases caused by fungi and bacteria. In: Handbook of orchid pests and diseases, American Orchid Society, 71-94

Cating, R. A. and A. J. Palmateer 2011 Bacterial soft rot of Oncidium orchids caused by a Dickeya sp. (Pectobacterium chrysanthemi) in Florida. Plant Dis. 95: 74

De Boer, S. H. and A. Kelman 2001 Erwinia soft rot group. In:
Schaad N. W., Jones J. B. and Chun W. Laboratory Guide for identification of plant pathogenic bacteria, Third Edition, Editors, APS Press. 62

Duyen, B. T. and N. V. Tuat 2012 Study on major diseases of boat orchids (Cymbidium sp.) and recommendation of control measures in $\mathrm{Sa} \mathrm{Pa}$, Lao Cai province. Sci. Technol. J. Agr. Rural Dev., 17 (In Vietnamese)

Edwards, U., T. Rogall, H. Blocker, M. Emde, E. C. Bottger 1989 Isolation and direct complete nucleotide determination of entire genes - characterization of a gene coding for 16S-ribosomal RNA. Nucleic Acids Res., 17: 7843-7853

Felsenstein, J. 1985 Confidence-limits on phylogenies - an approach using the bootstrap. Evolution, 39: 783-791

Furuya, N., S. Taura, T. Goto, B. T. Thuy, P. H. Ton, K. Tsuchiya and A. Yoshimura 2012 Diversity in virulence of Xanthomonas oryzae pv. oryzae from Northern Vietnam. JARQ, 46(4): 329338

Ha, N. T., N. T. T. Ha, P. X. Hoi and H. H. Long 2013 Occurrence of Cymbidium soft rot caused by Pectobacterium carotovorum in Sa Pa, Lao Cai. Sci. Technol. J. Agr. Rural Dev., 16 35-40 (In Vietnamese)

Han, K. S., S. C. Lee, J. S. Lee, J. W. Soh and S. Kim 2012 First report of Sclerotium rot on Cymbidium orchids caused by Sclerotium rolfsii in Korea. Mycobiology, 40(4): 263-264

Hauben, L., E. R. B. Moore, L. Vauterin, M. Steennackers, J Mergaert, L. Verdonck and J. Swings 1998 Phylogenetic position of phytopathogens within the Enterobacteriaceae. Syst. Appl. Microbiol., 21: 384-397

Jukes, T. H. and C. R. Cantor 1969 Evolution of protein molecules. In Munro HN, editor, Mammalian protein metabolism, Academic press, New York, 21-132

Kaenratana, K. 2009 Heat tolerant cymbidium. Amarin printing and publishing, Bangkok, 330

Kim, Y. K., S. D. Lee, C. S. Choi, S. B. Lee and S. Y. Lee 2002 Soft rot of onion bulbs caused by Pseudomonas marginalis under low temperature storage. Plant Pathol. J., 18(4): 199-203

Krejzar, V., J. Mertelík, I. Pánková, K. Kloudová, V. Kůdela 2008 Pseudomonas marginalis associated with soft rot of Zantedeschia spp. Plant Protect. Sci., 44: 85-90

Lane, D. J. 1991 16S/23S rRNA sequencing. In: Stackebrandt E, Goodfellow M, eds. Nucleic acid techniques in bacterial systematics. New York, NY, USA: Wiley, 115-148

Lee, B. D., W. G. Kim, W. D. Cho and J. M. Sung 2002 Occurrence of dry rot on Cymbidium orchids caused by Fusarium spp. in Korea. Plant Pathol. J., 18(3): 156-160

Marquez-Villavicencio, M. D. P., R. L. Groves and A. O. Charkowski 2011 Soft rot disease severity is affected by potato physiology and Pectobacterium taxa. Plant Dis., 95: 232-241

Schaad, N. W. 2001 Initial identification of common genera. In: Schaad N. W., Jones J. B. and Chun W. Laboratory guide for identification of plant pathogenic bacteria, Third Edition, Editors, APS Press. 1.

Sen, S., R. Acharya, A. Saha and K. Acharya 2006 A new report of Cymbidium spp. pseudobulb rot orchestrated by Erwinia carotovora, Fusarium oxysporum, and Mucor hiemalis f. sp. hiemalis. Plant Dis., 90(11): 1460

Sen, S., M. Rai, R. Acharya, S. Dasgupta, A. Saha and K. Acharya 2009 Biological control of pathogens causing the Cymbidium pseudobulb rot complex using fluorescent pseudomonas strain BRL-1. J. Plant Pathol., 91(3): 751-755

Smith, C. and J. A. Bartz 1990 Variation in pathogenicity and aggressiveness of strains of Erwinia carotovora subsp. carotovora isolated from different hosts. Plant Dis., 74: 505-509

Strider, D. L. 1985 Diseases of floral crops vol. 2 New York: Praeger Scientific, 638

Tamura, K., D. Peterson, N. Peterson, G. Stecher, M. Nei and S. Kumar 2011 MEGA5: Molecular evolutionary genetics analysis using maximum likelihood, evolutionary distance, and maximum parsimony methods. Mol. Biol. Evol., 28: 2731-2739

Vierheilig H., P. Schweiger and M. Brundrett 2005 An overview of methods for the detection and observation of arbuscular mycorrhizal fungi in roots. Physiol. Plantarum, 125: 393-404 